\title{
Fish diversity of Haryana and its conservation status
}

\author{
Anita Bhatnagar*, Abhay Singh Yadav and Neeru \\ Department of Zoology, Kurukshetra University, Kurukshetra, Haryana-136119, INDIA \\ "Corresponding author. E-mail: anitabhatnagar@gmail.com
}

Received: September 24, 2015; Revised received: April 7, 2016; Accepted: June 5, 2016

\begin{abstract}
The present study on fish biodiversity of Haryana state was carried out during 2011 to 2014 . A total number of 59 fish species inhabits the freshwaters of this state. Maximum number of fish species belonged to the order Cypriniformes (35) followed by the order Siluriformes (12) and Perciformes (8). The orders Beloniformes, Clupeiformes, Osteoglossiformes and Synbranchiformes were represented by only one species each. Out of 59 fish species, 2 are endangered, 11 vulnerable, 28 have lower risk of threat, 8 exotic and 4 fish species have lower risk least concern. The conservation status of six fish species has not been evaluated so far, hence they cannot be included in any of the IUCN categories at this moment. Family Cyprinidae alone contributed 32 fish species followed by Bagridae family. Fish species Parapsilorhynchus discophorus was observed for the first time in Haryana waters. This species is the native of Kaveri river basin, the occurrence of this species in river Yamuna may be attributed to some religious activity of people. A decline in fish diversity has been recorded from 82 species in 2004 to 59 species in the present study in the year 2014. The main causes for decrease in fish biodiversity are habitat destruction and fragmentation, changing practices of land use, exotic species introduction, fishing, irrigation needs, pollution and global climate change impacts. It is essential to prevent further decline of fish resources by devising all possible measures of conservation and rehabilitation.
\end{abstract}

Keywords: Biodiversity, Conservation, Freshwater, Pollution

\section{INTRODUCTION}

Biodiversity is the variation in the genetics and life forms of populations, species, communities and ecosystems (Hiddik et al., 2008). Biodiversity affects the capacity of living systems to respond to changes in the environment, and essential for providing goods and services from ecosystems. Thus it is the most valuable but least appreciated resource, and its understanding is essential for the maintenance of the world (Wilson, 1992). It is necessary to protect biodiversity in all ecosystems and is essential (whether for agriculture, fishery, forestry systems or evolutionary processes) for stabilization of ecological systems and protection of environmental quality for understanding intrinsic worth of all species on the earth (Ehrlich and Wilson, 1991). Among different ecosystems, freshwater ecosystems are the richest and the most diverse ecosystems on earth (Revenga and Mock, 2000). These comprise only $0.01 \%$ of the world's water and cover only $0.8 \%$ of the Earth's surface and generate nearly $3 \%$ of its net primary production (Alexander, 1999). Yet 6\% of all species, and more than $10 \%$ of all animal species, occur in fresh water, including $25 \%$ of all vertebrates and $40 \%$ of all fishes (Balian et al., 2008). Moreover, freshwater ecosystems contain $40 \%$ of the world's known fish species (Daily, 1997). Studies on diversity and conservation of fish fauna in Haryana is documented by few workers (Johal et al., 2002, 2012; Johal and Rawal, 2004; Negi et al., 2007; Johal and Jha, 2007, 2010; Vats and Gupta, 2011). Due to limitation of natural water body, pond fish farming contribute significantly to fish yield of the state following suitable management practices (Garg and Bhatnagar, 1996, 1999, 2000, 2002; Bhatnagar and Singh, 2010; Singh and Bhatnagar, 2010). However, with the increase in anthropogenic threats due to development and utilization of resources, a continuous monitoring of biodiversity is essential in this state comprising of two rivers, lakes and number of village ponds. Therefore, the present study was undertaken to monitor the pattern of decline of biodiversity which is essential for fisheries conservation in the Haryana state.

\section{MATERIALS AND METHODS}

Topography of the study area : The state of Haryana $\left(27^{\circ} 39^{\prime}\right.$ to $30^{\circ} 55^{\prime} \mathrm{N}$ and $74^{\circ} 28.8^{\prime}$ to $77^{\circ} 36.5^{\prime} \mathrm{E}$; Area $44,212 \mathrm{Km}^{2}$ ) is bounded by the river Yamuna in the East and Shivalik hills in the North. Rivers Yamuna and Ghaggar are the two main rivers flowing through the state. The fishery resources of Haryana include river length of $510 \mathrm{Km}$ (Yamuna river $305 \mathrm{Km}$ and Ghagger $205 \mathrm{Km}$ ), 12,900 $\mathrm{Ha}$ of lentic waters which include ponds, marshy lands, small reservoirs and water logged areas. The fish diversity of Haryana also includes some exotic fishes, which were intro- 


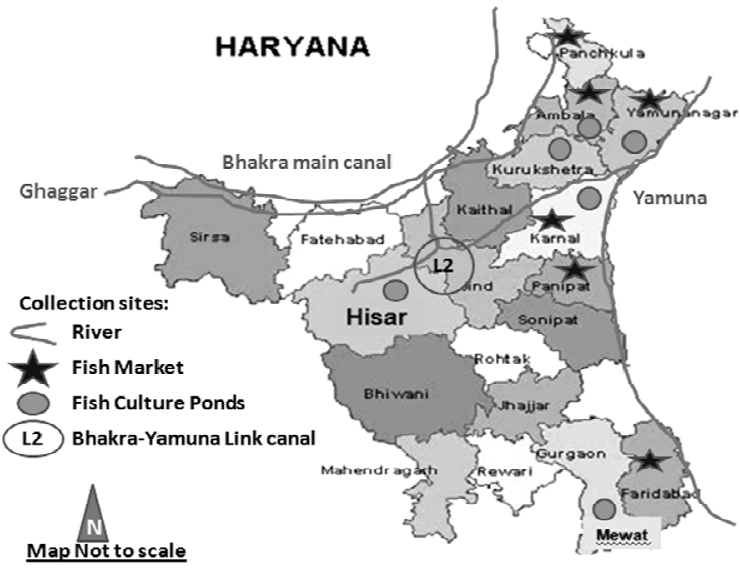

Fig. 1. Map of Haryana showing collection sites.

duced in the various water bodies for specific purposes and to increase the fish production. The area bordering the Western Rajasthan has Indus element as the canals originating from rivers Beas and Sutlej of the Indus river system irrigate this area (Johal and Rawal, 2004). All these aquatic ecosystems in Haryana comprised the study area for present study.

Collection of fishes: Fishes were collected at regular intervals from (i) Natural and manmade water bodies (viz., river Yamuna at Yamunanagar, Bhakra-Yamuna link at Narwana, fish culture village ponds in and around Kurukshetra, Yamunanagar, Ambala, Karnal, Hisar and Nuh Mewat) of Haryana with the help of local fishermen using cast net, gill net, drag net and hand net of various mesh sizes and (ii) from fish markets of Panchkula, Yamunanagar, Ambala, Karnal, Panipat and Faridabad. Fig. 1 depicts the map of Haryana showing location of rivers and districts from where ponds and fish markets were selected for sample collection. At the collection site, immediately photographs of fishes were taken with the help of digital camera Sony DSLR $\alpha 350$. One specimen of each species was preserved in $8 \%$ formalin solution and brought to the laboratory. Rest of the specimens were released back in the water bodies. The morphometric characters of the collected fishes were identified with the help of standard keys and monographs (Day, 1878; Johal and Tandon, 1979, 1980; Jayaram, 1999). Morphometric characters include Total length, Head length, Preorbital distance, Postorbital distance, Interorbital distance, Length of dorsal fin, Length of anal fin, Distance between pectoral and pelvic fin, Distance between pelvic and anal fin etc. Meristic counts like Dorsal fin rays, Pectoral fin rays, Pelvic fin rays, Anal fin rays, Caudal fin rays, Lateral line scales. The abundance status of fish species observed according to the percentage occurrence of that species. If a fish species was found greater than $70 \%$ in quantity in a catch, then it was represented as abundant $(++++)$. If the occurrence of any species was between 50-70\%, 30 $-50 \%$ and less than $30 \%$, then these were represented as common $(+++)$, moderate $(++)$ and rare $(+)$ respec- tively. The conservation status of different fish species has been assessed according to available literature as per IUCN criteria (Molur and Walker, 1998).

\section{RESULTS AND DISCUSSION}

During the present study 59 species of fishes belonging to 39 genera, 20 families and 7 orders were collected from various water bodies and fish markets of Haryana. Total number of fish species, common name, abundance, conservation status and locality of each species are presented in Table 1 . The maximum numbers of genera belonged to order Cypriniformes (20) followed by the order Siluriformes (9) and Perciformes (6). The orders Beloniformes, Clupeiformes, Osteoglossiformes and Synbranchiformes were represented by only one genus each. Maximum number of fish species belonged to the order Cypriniformes (35) followed by the order Siluriformes (12) and Perciformes (8). The order Beloniformes, Clupeiformes, Osteoglossiformes and Synbranchiformes included one species each. It has been observed that out of 59 fish species, two were endangered (EN), eleven vulnerable (VU), twenty eight lower risk near threatened (LRnt), eight exotic (Ex) and four lower risk least concerned (LRlc). The conservation status of six fish species has not been evaluated so far, hence they cannot be included in any of the IUCN categories at this moment. The fish fauna recorded in the present study depicts a mixture of hill stream and typical riverine fish species indicating that this state has varied ecological conditions. The study of fish fauna also include some exotic fish species, which appears to have been introduced some time back in confined waters for specific purposes such as pond fish production, eradication of macrophytes, and to control the algal bloom in ponds having high nitrogen content (Johal and Rawal, 2004). Some fishes like Gudusia chapra, Ctenopharyngodon idella, Cyprinus carpio communis, Hypophthalmichthyes molitrix and Salmophasia bacaila were observed in abundant quantity and these fishes do not need any special attention regarding conservation point of view. Catla catla and Clarias batracus were found to be in moderate quantity not very common in the present studies but IUCN status of both fishes showed that these are vulnerable. Barilius bola, Cirrhinus reba, $C$. carpio nudus, Labeo dyocheilus, L. gonius, Puntius amphibius, P. chola, P. terio, P. ticto, Notopterus notopterus, Heteropneustus fossilis, Eutropiichthyes vacha were observed rarely, while Bagarius bagarius was observed very rarely during the present investigations. Some fishes like Acanthocobitis botia, Amblypharyngodon mola, Aorichthyes aor, Badis badis, Botia dario, B. lohachala, Brachydanio rerio, Channa gachua, C. marulius, C. orientalis, Chitala chitala, Clupisoma garua, Crossocheilus latius, Gagata cenia, Garra gotyla, G. lamta, Glyptothorax indicus, Heteropneustes microps, Labeo angra, L. boga, L. caeruleus, L. dero, L. pangusia, Macrognathus 
Table 1. List of fish species collected during the present study.

\begin{tabular}{|c|c|c|c|c|c|}
\hline S.N. & Name of fish species & Local name & Abundance & $\begin{array}{l}\text { IUCN } \\
\text { status }\end{array}$ & Locality \\
\hline 1. & $\begin{array}{l}\text { Order- Beloniformes Family -Belonidae Xenentodon } \\
\text { cancila (Hamilton, 1822) }\end{array}$ & Takia machi & ++ & LRnt & $\begin{array}{l}\text { L1, } \\
\text { FM1,FM5 }\end{array}$ \\
\hline 2. & $\begin{array}{l}\text { Order- Clupeiformes Family- Clupeidae Gudusia } \\
\text { chapra (Hamilton, 1822) }\end{array}$ & & ++ & LRlc & $\begin{array}{l}\mathrm{L} 1, \mathrm{FM} 1, \mathrm{FM} \\
4\end{array}$ \\
\hline 3. & $\begin{array}{l}\text { Order - Cypriniformes Family - Cobitidae Botia birdi } \\
\text { Chaudhuri, } 1909\end{array}$ & Kander & ++ & LRnt & FM5 \\
\hline $\begin{array}{l}4 . \\
5 . \\
6 . \\
7 . \\
8 . \\
9 . \\
10 . \\
11 . \\
12 . \\
13 . \\
14 . \\
15 . \\
16 . \\
17 . \\
18 . \\
19 . \\
20 \\
21 \\
22 . \\
23 . \\
24 . \\
25 . \\
26 . \\
27 . \\
28 . \\
29 . \\
30 \\
31 . \\
32 . \\
33 . \\
34 . \\
35 .\end{array}$ & 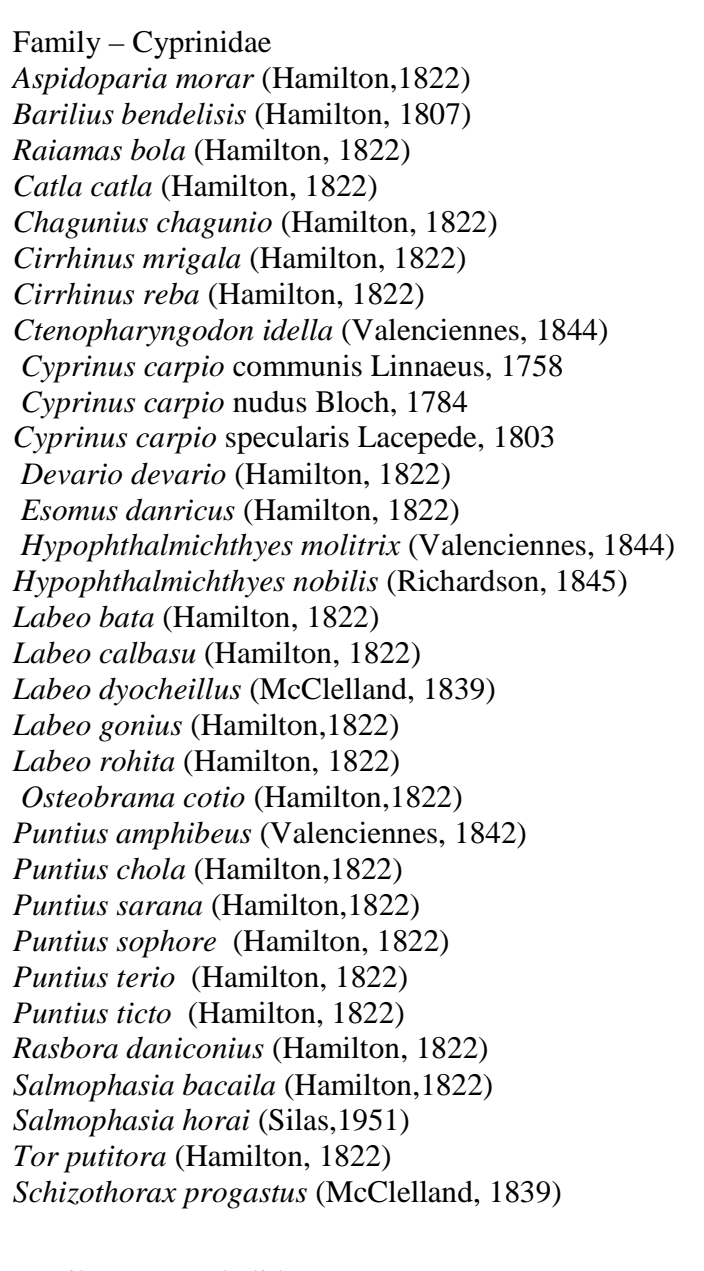 & $\begin{array}{l}\text { Asala } \\
\text { Kandri } \\
\text { Chilwa } \\
\text { Katla } \\
\text { Khadi } \\
\text { Mrigal } \\
\text { Mori } \\
\text { Grass carp } \\
\text { Golden } \\
\text { Leather } \\
\text { Mirror carp } \\
\text { Makhani } \\
\text { Dhoban } \\
\text { Silver carp } \\
\text { Bighead } \\
\text { Bata } \\
\text { Kalkoch } \\
\text { Lohan } \\
\text { Sirheen } \\
\text { Rohu } \\
\text { Seesa machi } \\
\text { Puthi } \\
\text { Puthi } \\
\text { Puthi } \\
\text { Chidhu } \\
\text { Puthi } \\
\text { Ticker } \\
\text { Chail } \\
\text { Chail } \\
\text { Mahaseer } \\
\text { Asala }\end{array}$ & $\begin{array}{l}++ \\
++ \\
+ \\
++ \\
++ \\
+++ \\
+ \\
++++ \\
+++ \\
+ \\
++ \\
++ \\
++ \\
+++ \\
+++ \\
++ \\
++ \\
+ \\
+ \\
++ \\
++ \\
+ \\
+ \\
+ \\
++ \\
+++ \\
+ \\
+ \\
++ \\
+++ \\
++ \\
++ \\
++\end{array}$ & $\begin{array}{l}\text { LRnt } \\
\text { LRlc } \\
\text { Ex } \\
\text { Ex } \\
\text { LRnt } \\
\text { LRnt } \\
\text { VU } \\
\text { LRnt } \\
\text { LRnt } \\
\text { LRnt } \\
\text { NE }\end{array}$ & $\begin{array}{l}\text { FM4, } \\
\text { FM5,L1 } \\
\text { L1,FM1,FM4 } \\
\text { L1,FM1,FM4 } \\
\text { L1, P3, P41 } \\
\text { L1, FM2 } \\
\text { P3, FM4 } \\
\text { FM5 } \\
\text { P2, P3, FM1 } \\
\text { L1, L2, FM4 } \\
\text { L1 } \\
\text { FM4, L2 }\end{array}$ \\
\hline 36. & $\begin{array}{l}\text { Family - Nemachelidae } \\
\text { Acanthocobitis botia (Hamilton, 1822) } \\
\text { Family - Parapsilorhynchidae }\end{array}$ & Sundli & ++ & LRnt & FM5 \\
\hline 37. & $\begin{array}{l}\text { Parapsilorhynchus discophorus Hora, } 1921 \\
\text { Order- Osteoglossiformes } \\
\text { Family- Notopteridae }\end{array}$ & Naaro & ++ & $\mathrm{NE}$ & L1 \\
\hline 38. & $\begin{array}{l}\text { Notopterus notopterus (Pallas, 1769) } \\
\text { Order- Perciformes } \\
\text { Family- Ambassidae }\end{array}$ & Pari & + & LRnt & FM4 \\
\hline 39. & Chanda nama Hamilton, 1822 & Seesa machi & +++ & LRnt & FM1, FM6 \\
\hline 40. & $\begin{array}{l}\text { Parambassis ranga (Hamilton, 1822) } \\
\text { Family- Channidae }\end{array}$ & Chitti Kangi & ++ & LRnt & FM3, FM4 \\
\hline 41. & Channa striatus (Bloch, 1793) & Dolla & +++ & LRlc & FM1, P1 \\
\hline 42. & $\begin{array}{l}\text { Channa punctatus (Bloch, 1793) } \\
\text { Family- Cichlidae }\end{array}$ & Goli & +++ & LRnt & FM5, FM2 \\
\hline 43. & Oreochromis mossambicus (Peters, 1852) & Tilapia & +++ & Ex & FM1 \\
\hline
\end{tabular}


Contd.

\begin{tabular}{|c|c|c|c|c|c|}
\hline 44. & $\begin{array}{l}\text { Family- Gobidae } \\
\text { Glossogobius giuris giuris (Hamilton, 1822) } \\
\text { Family- Osphronemidae }\end{array}$ & Gobi & +++ & LRnt & FM1,FM4, FM5 \\
\hline 45. & Colisa fasciatus Bloch \& Schneider, 1801 & Kangi & +++ & LRnt & FM1 \\
\hline 46. & $\begin{array}{l}\text { Colisa lalius (Hamilton, 1822) } \\
\text { Order- Siluriformes } \\
\text { Family- Bagridae }\end{array}$ & Kangi & +++ & LRnt & FM1 \\
\hline 47. & Aorichthyes seenghala (Sykes, 1839) & Seenghaa & +++ & LRnt & FM2 \\
\hline 48. & Mystus bleekeri (Day, 1877) & Kander & ++ & VU & FM2, FM4 \\
\hline 49. & Mystus cavasius (Hamilton,1822) & Kinger & ++ & LRnt & L1, FM5, \\
\hline 50. & Mystus vittatus (Bloch,1794) & Kala & ++ & VU & FM2 \\
\hline 51. & $\begin{array}{l}\text { Rita rita (Hamilton, 1822) } \\
\text { Family - Heteropneustidae }\end{array}$ & Khagga & ++ & LRnt & FM1 \\
\hline 52. & $\begin{array}{l}\text { Heteropneustes fossilis (Bloch, 1794) } \\
\text { Family- Claridae }\end{array}$ & Singhi & + & VU & FM1 \\
\hline 53. & Clarias batrachus (Linnaeus, 1758) & Magur & ++ & VU & FM4 \\
\hline 54. & $\begin{array}{l}\text { Clarias gariepinus (Burchell, 1822) } \\
\text { Family- Pangasidae }\end{array}$ & Thai Magur & ++ & NE & FM2, FM3 \\
\hline 55. & $\begin{array}{l}\text { Pangasius pangasius (Hamilton,1822) } \\
\text { Family- Schilbeidae }\end{array}$ & Salendhi & +++ & $\mathrm{NE}$ & FM1, FM2 \\
\hline 56. & $\begin{array}{l}\text { Eutropiichthys vacha (Hamilton,1822) } \\
\text { Family- Siluridae }\end{array}$ & Bacha & + & EN & L2 \\
\hline 57. & $\begin{array}{l}\text { Wallago attu (Bloch \& Schneider, 1801) } \\
\text { Family- Sisoridae }\end{array}$ & Mullee & ++ & LRnt & FM1, L1 \\
\hline 58. & $\begin{array}{l}\text { Bagarius bagarius (Hamilton, 1822) } \\
\text { Order- Synbranchiformes } \\
\text { Family- Mastacembelidae }\end{array}$ & Goonch & + & VU & FM5, FM6 \\
\hline 59. & Mastacembelus armatus (Lacepede, 1800) & Bam & + & $\mathrm{NE}$ & FM5 \\
\hline
\end{tabular}

Present status: $++++=$ Abundant, $+++=$ Common, $++=$ Moderate, $+=$ Rare; IUCN status: EN=Endangered; Ex $=$ Exotic; LRlc= Lower risk least concerned; LRnt=Lower risk near threatened; VU= Vulnerable; NE = Not evaluated; Locality: River Yamuna=L1; BhakhraYamuna link canal=L2; Fish market Yamunanagar=FM1; Ambala=FM2; Panchkula=FM3; Karnal=FM4; Panipat=FM5; Faridabad=FM6; Fish culture ponds of Yamunanagar=P1; Ambala=P2; Karnal=P3; Kurukshetra=P4; mHisar = P5; Nuh Mewat= P6

aculeatus, M. aral, M. pancalus, Nemacheilus denisoni, Ompak bimaculatus, O. pabda, Parambasis baculis, Pseudrotropiuys atherinoiders, Puntius conchonius, P. puntio, Raiamas bola, Rasbora daniconius, Salmostoma phulo, Schimatorhynchos nukta, Securicuila gora, Silonia silonida, Tor chelynoides, T. tor have been reported by Johal and Rawal (2004) from Haryana, but Johal and Jha (2007) did not reported these fishes. Also in the present study these fishes could not be collected except Acanthocobitis botia, Raiamas bola and Rasbora daniconius. The possible reasons are ecological degradation of natural water bodies, loss of flooding areas, thus diminishing the breeding grounds preventing their auto-stocking in nature and over exploitation of stocks have depleted their population. Therefore, it is clear that may be these fishes not present in freshwater bodies of Haryana or if present their number would be small, that is why these could not be collected. Johal and Jha (2007) reported some fishes like Lepidocephalus guntea, $\mathrm{Ne}$ macheilus denisoni denisoni, Amblypharyngodon mola, Barilius barila, B. vagra, Chela cachius, Garra gotyla gotyla, Labeo angra, L. dero, Salmostoma phulo panjabansis, Amblyceps mangois, Clarias gariepinnus, Heteropneustus microps, Glyptothorax indicus, G. telchitta, Gambusia affinis, Channa gachua, $C$. marulius, Badis badis. But these fishes were not col- lected during the present study. During the present study some fishes like Cyprinus carpio nudus, Devario devario, Esomus danricus, Puntius amphibeus, $P$. sarana, Rasbora daniconius, Salmophasia horai, Schizothorax progastus, Parapsilorhynchus discophorus, Colisa lalius, Rita rita, Pangasius pangasius, Eutropiichthyes vacha have been encountered but these fishes were not reported by Johal and Jha (2007). Out of these species, $P$. discophorus is that species which was reported first time from Haryana. This particular fish showed $75 \%$ similarity in morphological characters with $P$. discophorus but $25 \%$ with that of genus Garra according to the identification key of Jayaram (1999). That is why it was identified as Parapsilorhynchus discophorus. This particular fish is the native of Kaveri river basin. According to Dahanukar (2011), P. discophorus is assessed as vulnerable as its breeding habitat on the mountain top is threatened due to habitat modification by recreational activities. The reason behind the occurrence of this species in river Yamuna might be some religious activity of people. Sometimes aquarium fishes are released into the natural water bodies by local people based on their religious beliefs. There may also be a reason that it might have entered into river Yamuna along with some other fishes with some stream. Amongst these species Devario devario, Salmophasia horai, Schizothorax progastus, Rita rita, 
Pangasius pangasius, Eutropiichthyes vacha are carnivorous fishes. Esomus danricus, Puntius sarana, Rasbora daniconius and Colisa lalius are omnivorous fishes while Puntius sarana and Parapsilorhynchus discophorus are herbivorous fishes. Out of the 59 fish species, 8 exotic fishes have been reported (Table 1). Exotic species of fishes were introduced in many parts of the world for improving local fishery potential, broadening species diversity in aquaculture programmes, sport fishing, aquarium keeping and controlling of unwanted organisms (Kumar, 2000). The indiscriminate transfer of exotic fishes brought about a worldwide concern as it resulted in a wide array of problems including extirpation of indigenous species. The exotics are a competition to indigenous fishes for food and habitat. They may prey upon native fishes, introduce new diseases and parasites, results in the production of hybrids and cause genetic erosion of indigenous species and degradation of the physicochemical nature of aquatic ecosystems. All this will subsequently lead to loss of biodiversity (Nyman, 1991). In the present study these exotic species such as Ctenopharyngodon idella, $C$. carpio communis, $C$. carpio specularis, Hypophthalmichthyes molitrix, Hypophthalmichthyes nobilis and Oreochromis mossambicus were found to be abundant or common at most of collection sites supporting the view that sometimes population of these species become so abundant that it affect the population of native species (Kumar, 2000). Moreover, the presence of these exotic species is not viewed positively (Johal and Tondon, 1983; Welcomme, 1988). Cyprinus carpio nudus is the only exotic species which was reported rarely. This species was collected only from river Yamuna. The reason behind the rare occurrence of this species may be due to less survival rate.

Out of 59 fish species, some aquarium fishes like Xenentodon cancila, Barilius bendelisis, Devario devario, Esomus danricus, Acanthocobitis botia, Parambassis ranga, Colisa fasciatus and $C$. lalius were reported. The human activities that have been causing destruction to the fishery are overfishing (more for commercial purposes than for living) and pollution of the aquatic systems, mainly due to discharge of domestic/ industrial effluents into the aquatic systems. Jhingran (1984) and Das and Barat (1990) have also stated similar reasons about declining fish biodiversity. Thus there is a need to discuss conservation issues in Indian river systems (Menon, 1989; Dubey, 1994; Anonymous, 1995; Kapoor and Sarkar, 2005). Along with enlisting the available species and comparing them with previously documented literature there is a need to ascertain the conservation status of reported fishes. The present study shows that Ctenopharyngodon idella, Cyprinus carpio communis, Hypophthalmichthyes molitrix and Salmophasia bacaila were found in abundant (++++) quantity. All species are exotic except $S$. bacaila. IUCN also declared $S$. bacaila in LRnt category. All the Indian major carps were found commonly in wild as well as these are important culturable fishes in pond fish culture. Catla catla need some attention because IUCN declared $C$. catla as VU species. Minor carps like Labeo bata, Labeo calbasu were moderately $(++)$ reported in present study but IUCN criteria of these species shows that they fall under LRnt category. Cirrhinus reba, Labeo dyocheilus and Labeo gonius were reported rarely (+). According to IUCN these species are VU. Majority of the fish species were found in moderate (++) quantity. Fish species which were found rarely (+) like Puntius chola, $P$. terio, Raiamas bola, Notopterus notopterus, Heteropneustes fossilis, Eutropiichthyes vacha, Bagarius bagarius and Mastacembelus armatus need some special attention. There are several ways to reverse the trend of inclusion of fish species in one of the IUCN conservation categories e.g. periodic extensive ichthyofaunal surveys, ascertaining the conservation status of reported fish species, identification and protection of breeding and feeding grounds of fishes and finally declaration of ecologically undisturbed aquatic bodies (Johal and Rawal, 2004). In situ conservation is one of the several prominent and suggestive measures for conservation of fish biodiversity.

\section{Conclusion}

The ichthyological survey conducted during the period 2011 to 2014 has revealed that the different water bodies of present day Haryana support 59 fish species belonging to 7 orders. It is concluded that due to urbanization, different water management practices and rapid pollution of most of the aquatic bodies in the state, the fish diversity of Haryana show significant changes, when compared with the earlier reports of fish diversity study. It indicates that there is a change in water quality. It is suggested that to evaluate the loss or gain of fish diversity, periodic ichthyological survey must be undertaken and there should be strict regulations for stress causing anthropogenic activities.

\section{REFERENCES}

Alexander, D.E. (1999). Encyclopedia of Environmental Science. Springer. ISBN. 0-412-74050-8. pp. 136-137.

Anonymous. (1995). Perspective plan of NBFGR (Indian Council of Agriculture Research).

Balian, E., Segers, H., Levenque, C and Martens, K. (2008). The fresh water animal diversity assessment: an overview of the results. In Balian, E. et al. (Eds), Fresh water Animal Diversity Assessment. Hydrobiologia, 595: 627-637.

Bhatnagar, A. and Singh, G. (2010). Assessment of culture fisheries in village ponds: a study in district Hisar, Haryana, India. International Journal of Environmental Research, 4 (1): 57- 64.

Dahanukar, N. (2011). Parapsilorhynchus discophorus. In: IUCN 2011. IUCN Red List of Threatened Species. Version 2011.2. <www.iucnredlist.org>. Downloaded on 03 March 2012.

Daily, G.C. (1997). Nature's Services. Island Press. ISBN 1- 
559-63476-6.

Das, P. and Barat, A. (1990). Fish habitat degradation necessitating conservation. Environmental Series 4: 85-89.

Day, F. (1878). The fishes of India. W.W. Bawson and sons Ltd., London.

Dubey, G.P. (1994). Endangered vulnerable and rare Fishes of West Coast River System of India. Threatened fish of India, Netcon Publication, 4 (1):11-20.

Ehrlich, P.R. and Wilson, E.O. (1991). Biodiversity studies: Science and policy. Science, 253:758.

Garg, S.K. and Bhatnagar, A. (1996). Effect of varying doses of organic and inorganic fertilizers on plankton production and fish biomass in brackish water ponds. Aquaculture Research, 27: 157-166.

Garg, S.K. and Bhatnagar, A. (1999). Effect of different doses of organic fertilizer (cowdung) on pond productivity and fish biomass in still water ponds. Journal of Applied Ichthyology, 15: 10-18.

Garg, S.K. and Bhatnagar, A. (2000). Effect of fertilization frequency on pond productivity and fish biomass in still water ponds. Aquaculture Research, 31: 409-414.

Garg, S.K. and Bhatnagar, A. (2002). Determination of optimum dosage of Azotobacter vis-a-vis organic fertilizer for optimum pond productivity in fresh water ponds. Aquaculture International, 10: 87-107.

Hiddik, J.G. MacKenzie, B.R. Rijnsdorp, A. Dulvy, N.K. Nielson, E.E. Bekkevold, D. Heino, M., Lorance, P. and Ojaveer, H. (2008). Importance of fish biodiversity for the management of fisheries and ecosystems. Fisheries Research, 90:6-8.

Jayaram, K.C. (1999). Freshwater fishes of Indian region. Narendra Publishing House, Delhi.

Jhingran, A.G. (1984). The Fish Genetic Resources of India. Indian Council of Agricultural Research, New Delhi.

Johal, M.S. and Jha, S.K. (2010). Ichthyofaunal composition and conservation status of five North Indian States (Haryana,Himachal Pradesh, Punjab, Rajasthan and Uttrakhand). Pb. Univ. Res. Bull., 60: 19-39.

Johal, M.S. and Rawal, Y.K. (2004). Status of Haryana fish diversity and its conservation. Pp 150161. Proc. National Workshop on rational use of water resources for aquaculture(eds. S.K. Garg and K.L. Jain). March 1819, 2004. HAU, Hisar, Haryana.

Johal, M.S. and Tandon, K.K. (1979). Monograph on the fishes of re-organised Punjab. Part I. Punjab Fisheries Bulletin, 3:1-44.

Johal, M.S. and Tandon, K.K. (1980). Monograph on the fishes of re-organised Punjab. Part II. Punjab Fisheries Bulletin., 4: 39-70.

Johal, M.S. and Jha, S.K. (2007). Fish diversity of Haryana state and its conservation status. Fishing Chimes., 27 (1): $107-108$.
Johal, M.S. and Tandon, K.K. (1983). The decline of native fishes. Punjab Fisheries Bulletin, 7: 3-15.

Johal, M.S., Jha, S.K. and Rawal, Y.K. (2012). Monograph on the fishes of Haryana state (India). Panjab University Research Journal (Science), 62: 1-47.

Johal, M.S., Tandon, K.K., Tyor, A.K. and Rawal, Y.K. (2002). Fish diversity in different habitats in the streams of lower middle Himalayas. Poland Journal of Ecology, 50 (1): 45-56.

Kapoor, D. and Sarkar, U.K. (2005). Priority Research Components of NBFGR for conservation of Indian fish biodiversity. Fishing Chimes., 25 (1): 110-113.

Kumar, A.B. (2000). Exotic fishes and freshwater fish diversity. Zoos' Print Journal, 15 (11): 363-367.

Menon, A.G.K. (1989). Conservation of Ichthyofauna of India, In: Conservation and management of Inland capture fisheries resources of India (Editors: Jhingran A.G. Sugunan, VV eds.). The inland fisheries society of India. Pp25-33.

Molur, S. and Walker, S. (1998). Report on the workshop 'conservation assessment and management plan for Freshwater fishes of India'. Zoo Outreach Organization, Conservation breeding specialist Group India, Coimbatore India. pp 156.

Negi, R.K., Joshi, B.D., Negi, T. and Chand, P. (2007). A study on stream morphology of someselected hillstreams of District Nainital with special reference to its biotic communities. In: Preceedings of DAE-BRNS National Symposium on Limnology (NSL-07), (eds. B.Venkatramani, V.D. Puranik, S.K. Apte, H.N. Gaur, L.L. Sharma, S.K. Sharma, V.S. Durve, H.C.C. Gupta, P.C. Verma, B.K. Sharma). Pp288-295.

Nyman, L. (1991). Conservation of freshwater fish. Protection of biodiversity and genetic variability in aquatic ecosystems. Fisheries Development Series. 56. Swedmar and WWF, Swedon pp 38.

Revenga, C. and Mock, G. (2000). Freshwater biodiversity in crisis. Earth Trends World Resources Institute: 1-4. (http.//earthtrends.wri.org).

Singh, G. and Bhatnagar, A. (2010). Relations between water Quality Characteristics and fish yields in small scale culture ponds in Yamunanagar, Haryana. Enviornment and Ecology, 28 (3): 1615-1619.

Vats, R. and Gupta, S.K. (2011). Ichthyofauna of four districts of Northern Haryana. Journal of Arts, Science and Commerce, 2 (4): 23-29.

Welcomme, R.L. (1988). International introductions of Inland aquatic species. FAO Fish. Tech.Pap. 294. Pp. 1-318.

Wilson, E.O. (1992). Diversity of life. Norton: W.W. and Company, Inc., P.424. 